\title{
Health Status and Physical Fitness of Urban Working and Non -Working Women in Dharwad Taluk, India
}

\author{
Channamsetty Mahalakshmi ${ }^{1}$, Suma Hasalkar ${ }^{2}$, SaritaKumari $^{1}{ }^{*}$ and Mani Bhushan ${ }^{3}$ \\ ${ }^{1}$ Department of Family Resource Management, College of Community Science, \\ Assam Agricultural University, Jorhat - 785013, Assam, India \\ ${ }^{2}$ Department of Family Resource Management, College of Community Sciences, \\ UAS, Dharwad - 580005, Karnataka, India \\ ${ }^{3}$ BholaPaswanShastri Agricultural College, Purnea-854 302 Bihar, India \\ *Corresponding author
}

\section{A B S T R A C T}

\section{Keywords \\ Body mass index, Per cent fat, Lean body mass, Aerobic capacity, Physical fitness}

\section{Article Info}

Accepted:

14 May 2020

Available Online:

10 June 2020
In this study we attempted to measure physical fitness in terms of women's aerobic capacity (VO2 max). Objective: to evaluate the socio-economic status, to analyze the physical and physiological parameters and to evaluate the physical fitness of the selected urban women using a step ergometer. The study sample consisted of 60 women from urban areas. The data were collected by the interviewees using the personal interview method using a structured interview program previously assessed. Physical measurement tools such as road anthropometric, scale, skinfold clamps, digital B.P openings, dynamo grip were used to record the data. Socioeconomic status shows that more than 60 percent of urban respondents belonged to the lower middle class. The average age of the interviewees was over 33.55 years with an average height of over 159 , the average weight of $56.95 \mathrm{~kg}$. Mean blood pressure, pulse rate, body temperature and grip strength were normal. More than 23.33 percent belonged to the normal underweight body mass index and the normal range category respectively. The average fat weight between the two categories was $11 \mathrm{~kg}$, with a lean mass of $45 \mathrm{~kg}$. The average fat percentage was above $19 \%$ and body density was 1.05 . More than 60 percent fell on the mesomorphic body type and medium and good category aerobic capacity. The step ergometric exercise showed that most urban respondents belonged to the low level of average physical conditions.

\section{Introduction}

Every person has a diverse level of physical fitness which may alter with time, place of work and situation. There is also correlation among the daily activities and the fitness of an individual. From the physiological point of view, physical fitness may said to be the capability of the body to adopt and recover from strenuous exercise. (Chaudhary 1998) Physical fitness is the capacity to withstand different forms of physical activities reasonably well, without being unduly tired and is a measure of individual's health and well-being. The relationship between physical activity and fitness was established by 
(Boucher and Shepherd 1994). The expert committee of the World Health Organization (1981) described physical fitness as "the ability to take on muscular work satisfactorily." Physical fitness is the capability to withstand various forms of physical activities rationally well, without being unduly tired and is a measure of individual's health and well-being.

The term fitness refers to the physiological fitness or cardio respiratory fitness and is determined from the maximum aerobic power (VO2 max) of an individual. In order to ensure health and safety of people at work, demand and fitness should match.

It is known that every individual has certain potential work capacity known as aerobic capacity (VO2 Max) a fraction of which is utilized while performing a given task. Physical fitness of women is considered as an essential element for understanding her endurance and sustainability of managing the work loads of different activities.

The present study helps to examine the physical fitness of women in terms of its demands placed on cardiovascular system during step test exercise. The present study is conducted with the objective to analyse the physical fitness of the rural and urban women with the objectives, to analyze the physical and physiological parameters of fitness among rural and urban women and to assess the physical fitness of the selected rural and urban women by using step test ergometer.

\section{Materials and Methods}

The study was conducted in Dharwad district of Karnataka with the sample size of 60 nonpregnant and non-lactating women without any cardio respiratory complaints from the age group of 20-45 years were selected in order to achieve the objectives of the present investigation. Physical characteristics like height and weight was measured by using anthropometric road and weighing balance.

Physiological characteristics like blood pressure, pulse rate, grip strength and body temperature were recorded by using automatic blood pressure monitor, grip dynamometer and digital clinical thermometer respectively.

The health status of an individual can be accessed through various parameters like body mass index, body fat percent, body type and aerobic capacity.

Body mass index is an effort to quantify the amount of tissue mass (muscle fat and bone) in an individual and classify that person as underweight, normal weight, overweight and obese based on the value, by using the following formula given by Garrow et al (1981)

BMI $\left(\mathrm{kg} / \mathrm{m}^{2}\right)=\frac{\text { Weight }(\mathrm{kg})}{\text { Height }\left(\mathrm{m}^{2}\right)}$

Body composition includes body density, fat content of the body and estimation of lean body mass. These are determined from compiling the data on skin fold thickness measured at four sites, i.e. bicep, tricep, subscapular and suprailiac with the help of skin fold callipers.

The following formulae were used to assess the body composition.

Body density (D) $=1.1599-(0.0717 \times \log$ of sum of 4 skin folds)

Per cent fat $=(4.95 / D-4.5) \times 100$

Fat weight $=$ Body weight $\mathrm{x}$ Per cent fat $/ 100$

Lean body mass $(\mathrm{kg})=$ Body weight - Fat weight 
Body somato type is the method of classifying the human physique based on height and weight by using the following formula and can classified based on their ponderal index score (PI) by using following formula.

$\mathrm{PI}=1000 x^{\frac{\sqrt{\text { weight }(\mathrm{kg})}}{3 \text { height }(\mathrm{cms})}}$

Aerobic capacity $\left(\mathrm{VO}_{2} \max \right)$ or maximal oxygen uptake is the consumption of maximum volume of oxygen (VO2 max) which was estimated based on the body weight and age of the subjects by using the following formula and later the subjects are classified into various physical fitness categories according to the classification given by Saha et al (1996).

VO2 max $(1 / \mathrm{min})=0.023 \times$ Body weight $(\mathrm{kg})$ -0.034 x Age $(\mathrm{yrs})+1.652$

VO2 $\max (\mathrm{ml} / \mathrm{kg} \cdot \min )=\mathrm{VO} 2 \max (1 / \mathrm{min}) /$ Body weight $\mathrm{x} 1000$

Physical fitness of women is determined by using various methods. In this study step test ergometer was used to assess the physical fitness. This is a simple method of measuring the ability of one's circulatory capacity to recover from the exercise of an endurance nature. The heart rate responses were recorded by using the polor heart rate monitor. The subjects were asked to rest for five minutes and do the step tests exercise on the ergometer until they get exhausted. Immediately after exercise the subjects were asked to sit for five minutes.

The heart rates after exercise were recorded during recovery time of five minutes. Based on recovery heart rate data the physical fitness index was calculated by using the following formula later the subjects were classified as per the classification score given by (Varghese et al., 1994).
Physical Fitness Index $=\frac{\text { Duration of stepping }(\mathrm{sec} .)}{\text { Sum of I,II \& III min recovery heart rare }}$ X 100

\section{Results and Discussion}

In urban working and non-working women 46.67 per cent and 50per cent belonged to the age group of 38 years and above respectively followed by 36.67per cent and 33.33per cent belonged to the age group of 35-37 years. Only 16.67 per cent in both groups belonged to the age group of less than 34 years.

Whereas in total urban sample more than 60 per cent of the respondents were married in both working and non-working categories, followed by 13.33 per cent each were unmarried. More than 10per cent were single, and 6.67per cent were widows and only 3.33 per cent divorced in both categories. Further, the data on education of selected urban working women 40.00 per cent were graduates, followed by 33.33 per cent were studied up to P.U.C, 10.33 per cent had secondary schooling, and 6.66 per cent post graduates

Only 3.33 per cent were illiterates. Among urban non-working group 33.33 per cent were graduates, followed by 23.22 per cent studied up to P.U.C, 20.00 per cent up to high school education, 10.00 per cent completed primary school and none of them were Illiterates. Majority of the urban respondents (51.67\%) were house wives or labourers, followed by an equal per cent of 16.67 were serving in private sector and in central or state or public sectors. Almost 11.67 per cent were serving at shops, home, transport, agriculture. Only 3.33 per cent were self-employed. An equal per cent of 33.33 per cent urban working women were serving in private sector and in central or state or public sectors, followed by 23.23 per cent serving at shops, home, transport, agriculture, 6.67 per cent self-employed and only 3.33 per cent were labourers. 
Among all the urban non-working respondents were house wives. Among urban working category 33.33 per cent were having monthly income level ranging between Rs. 20000 to Rs. 49999 per month fallowed by 23.33 per cent were having monthly income level ranging between Rs. 5000 to Rs. 9999 per month, 16.67 per cent were having income ranging between Rs. 10000 to Rs. 19999 per month, and an equal percent of 13.33 67 per cent were having income ranging between Rs. 1000 to Rs. 2499 and Rs. 2500 to Rs. 4999 per month. Among urban non-working category all the respondents were housewife's so they were having income less than Rs. 5000 per month as shown in table-1.

Life style factors such as type of food consumed, Time expenditure pattern of daily activities, performance of exercises also. Type of food consumed in urban area majority of $(58.33 \%)$ the women were vegetarians followed by non-vegetarians group $(28.33 \%)$. Very less percent $(13.33 \%)$ of the women were eggatarians. A glance in to the urban working and non-working respondents revealed that more than half of the women $(60.00 \%$ and $56.67 \%)$ were vegetarians, followed by 26.67 per cent and 28.33 per cent non vegetarians. Only 16.67 per cent and 13.33 per cent were eggatarians in working and non-working women as shown in table-2.

Similarly urban women spent 7 hours 29 minutes for sleeping, 7 hours 22 minutes for paid work, 4 hours 13 minutes for other house hold activities, 3 hours 23 minutes for cooking, 3 hour 19 minutes for rest and recreation and 2 hour 20 minutes for personal activities. The table notifies that on an average a urban working women spend 7 hours 28 minutes for sleeping, 7 hours 22 minutes for paid work, 4 hours 24 minutes for other house hold activities, 2 hours 14 minutes for cooking, 1 hour 25 minutes for rest and recreation, and 1 hour 12 minutes for personal activities.

Urban non-working women spend 7 hours 16 minutes for sleeping, 5 hour 10 minutes for rest and recreation, 4 hours 12 minutes for other house hold activities, 4 hours 05 minutes for cooking, and 3 hour 14 minutes for personal activities as shown in table-3.

Out of the total respondents 45.00 per cent did not exercise at all. Whereas 41.67 per cent of the respondents did exercise daily, followed by 6.67 per cent doing exercise weekly, 6.67 per cent did exercise occasionally. Among both working and non-working category of urban respondents maximum per cent (43.67\% and $43.33 \%$ respectively) did not do exercise at all. Among the remaining respondents equal percentage of women (36.67\%) exercised daily in both working and non-working category respectively. A very meager percentage $(6.67 \%$ and $13.33 \%)$ of the respondents did exercise weekly and occasionally respectively.

In urban areas 23.33 per cent of the women preferred to do walking followed by 13.33 per cent preferred doing yoga and only 8.33 per cent preferred to do physical exercise. Very less per cent of women $(6.67 \%)$ preferred doing both walking and exercise or walking exercise and yoga together. Simile trend was followed by both working and non-working in urban areas. In urban working category 23.33 per cent of the women spent about 20 minutes followed by 13.33 per cent spent about 30 minutes and 6.67per cent spent 40 minutes for exercise.

Only 3.33 per cent each spent about 10 minutes, 50 minutes and 60 minutes for exercising. In urban non-working category 16.76 per cent of the women spent about 20 minutes for exercise followed by 13.33 per cent spent about 30 minutes for exercise and 10 per cent each spent about 40 minutes and 
10 minutes. Only 3.33 per cent each spent about 50 minutes and 60 minutes as shown in the table-4. An observation of the data in table-5 revealed that the mean height was $160.35 \mathrm{cms}$ and the mean weight was 56.95 kgs. In urban working and non-working category the mean age of the women was 33.27 years and 33.83 years. Mean height wes $159.98 \mathrm{cms}$ and $158.12 \mathrm{cms}$ and mean weight was $57.57 \mathrm{kgs}$ and $59.40 \mathrm{kgs}$.

The data of urban women revealed the mean blood pressure was $119.38 / 80.30$ with the pulse rate of 81.11 beats/min, and body temperature of $96.78^{\circ} \mathrm{F}$. The mean grip strength of right and left hand of the respondents was $13.89 \mathrm{~kg}$ and $13.76 \mathrm{~kg}$ respectively. The mean blood pressure among urban working women category was observed to be $118.72 / 81.70$ with the pulse rate of 81.11 beats/min and body temperature of $96.80^{\circ} \mathrm{F}$. The mean grip strength of right and left hand of the respondents was $14.68 \mathrm{~kg}$ and $14.68 \mathrm{~kg}$ respectively. The mean blood pressure among urban non-working women category was observed to be $120.73 / 81.70$ with the pulse rate of $81.50 \mathrm{beats} / \mathrm{min}$ and body temperature of $96.70^{\circ} \mathrm{F}$.

The mean grip strength of right and left hand of the respondents was $13.10 \mathrm{~kg}$ and $12.96 \mathrm{~kg}$ respectively. The mean fat weight in urban women was found to be $11.86 \mathrm{~kg}$, with the lean body mass of $45.09 \mathrm{~kg}$. The mean fat percentage was 20.65 and the body density was 1.05. The mean fat weight among urban working category was found to be $12.17 \mathrm{~kg}$ with the lean body mass of $47.23 \mathrm{~kg}$, mean fat percentage of 20.19 and the body density of 1.05. Whereas the urban non-working category showed the mean fat weight of $11.55 \mathrm{~kg}$ with the lean body mass of $42.95 \mathrm{~kg}$. The mean fat percentage of 21.11 and the body density of 1.05 . It was clear from the table- 6 that an equal percentage of the urban women $(23.33 \%)$ belonged to low weight normal range and normal range of body mass index followed by again equal percentage of 18.33 women belonged to CED Grade I- Mild and CED Grade II-Moderate category. About 16.67 per cent belonged to CED Grade IIISevere category of body mass index. None of the urban women were in Obese grade-I, Obese grad-II category of body mass index shown in the methodology table-10. Maximum percentage of urban working women $(40.00 \%)$ belonged to normal range body mass index category followed by 26.67 per cent belonged to CED Grade I- Mild, 16.67 per cent belonged to low weight normal category, 13.33 per cent belonged to CED Grade III-Severe category of body mass index. Only 3.33per cent belonged to CED Grade II-Moderate category of body mass index.

Whereas maximum percentage of urban nonworking women $(33.33 \%)$ belonged to CED Grade II-Moderate category of body mass index, followed by 30.00 per cent belonged to low weight normal category 20.00 per cent to CED grade-III Severe and 10.00 per cent of the to CED Grade I- Mild category of body mass index.

Only and 6.7 per cent belonged to normal category of body mass index Similarly the majority of the urban respondents the $(70 \%)$ fell in the category of mesomorph body type followed by endomorph body type (23.33\%) and only 6.67 per cent fell in ectomorph body type. Majority of the urban women in both urban working and non-working category $(63.33 \%$ and $70.00 \%)$ respectively belonged to mesomorph body type followed by 36.67 per cent and 10.00 per cent in both urban working and non-working belonged to endomorph body type respectively. None of the respondents belonged to ectomorph body type in urban working category where as in urban non-working category only 13 per cent were belonged to ectomorph category. 
Table.1 Demographic profile of the selected rural and urban respondents

\begin{tabular}{|c|c|c|c|}
\hline \multirow{2}{*}{ Particulars } & \multicolumn{3}{|c|}{ Urban Women } \\
\hline & Working $(\mathrm{n}=\mathbf{3 0})$ & Non-Working $(\mathrm{n}=\mathbf{3 0})$ & Total $(n=60)$ \\
\hline \multicolumn{4}{|c|}{ Ten } \\
\hline$\leq 34$ & $5(16.67)$ & $5(16.67)$ & $10(16.67)$ \\
\hline $35-37$ & $11(36.67)$ & $10(33.33)$ & $12(35.00)$ \\
\hline$\geq 38$ & $14(46.67)$ & $15(50.00)$ & $29(48.33)$ \\
\hline \multicolumn{4}{|l|}{ Marital status } \\
\hline Married & $19(63.33)$ & $20(66.67)$ & $39(65.00)$ \\
\hline Un married & $4(13.33)$ & $4(13.33)$ & $8(13.33)$ \\
\hline Single & $3(10.00)$ & $4(13.33)$ & $7(11.67)$ \\
\hline Widow & $2(6.67)$ & $2(6.67)$ & $4(6.67)$ \\
\hline Divorce & $2(6.67)$ & $0(0.00)$ & $2(3.33)$ \\
\hline \multicolumn{4}{|l|}{ Education } \\
\hline Illiterate & $1(3.33)$ & $0(0.00)$ & $1(1.67)$ \\
\hline Primary school & $2(6.67)$ & $3(10.00)$ & $5(8.33)$ \\
\hline High school & $3(10.00)$ & $6(20.00)$ & $9(15.00)$ \\
\hline P.U.C & $10(33.33)$ & $7(23.33)$ & $17(28.33)$ \\
\hline Graduation & $12(40.00)$ & $10(33.33)$ & $22(36.67)$ \\
\hline Post-graduation & $2(6.67)$ & $4(13.33)$ & $6(10.00)$ \\
\hline \multicolumn{4}{|l|}{ Occupation } \\
\hline $\begin{array}{l}\text { Income less than } 5000 \\
\text { (labourer, house wife) }\end{array}$ & $1(3.33)$ & $30(100)$ & $31(51.67)$ \\
\hline Self employed & $2(6.67)$ & - & $2(3.33)$ \\
\hline $\begin{array}{l}\text { Service at shops, home, } \\
\text { transport, agriculture. }\end{array}$ & $7(23.33)$ & - & $7(11.67)$ \\
\hline Service in Private sector & $10(33.33)$ & - & $10(16.67)$ \\
\hline $\begin{array}{l}\text { Service in } \\
\text { central/State/Public }\end{array}$ & $10(33.33)$ & - & $10(16.67)$ \\
\hline \multicolumn{4}{|l|}{ Income (Rs-per month) } \\
\hline Less than 1000 & $0(0.00)$ & - & $0(0.00)$ \\
\hline $1000-2499$ & $4(13.33)$ & - & $4(6.67)$ \\
\hline $2500-4999$ & $4(13.33)$ & - & $4(6.67)$ \\
\hline 5000-9999 & $7(23.33)$ & - & 7 (11.67) \\
\hline 10000-19999 & $5(16.67)$ & - & $5(8.33)$ \\
\hline 20000-49999 & $10(33.33)$ & - & $10(16.67)$ \\
\hline More than 50000 & $0(0.00)$ & - & $0(0.00)$ \\
\hline
\end{tabular}


Table.2 Type of food consumed by the selected urban respondents

\begin{tabular}{|l|c|c|c|}
\hline \multirow{2}{*}{ Type of food in take } & \multicolumn{3}{|c|}{ Urban Women } \\
\cline { 2 - 4 } & Working (n=30) & Non-Working (n=30) & Total (n=60) \\
\hline Vegetarian & $18(60.00)$ & $17(56.67)$ & $35(58.33)$ \\
\hline Non vegetarian & $9(30.00)$ & $8(26.67)$ & $17(28.33)$ \\
\hline Eggtarian & $3(10.00)$ & $5(16.67)$ & $8(13.33)$ \\
\hline
\end{tabular}

Table.3 Time expenditure pattern of daily activities by the selected urban respondents in hours

\begin{tabular}{|l|c|c|c|}
\hline \multicolumn{1}{|c|}{ Activities } & \multicolumn{3}{|c|}{ Urban Women } \\
\cline { 2 - 4 } & $\begin{array}{c}\text { Working }(\mathbf{n}=\mathbf{3 0}) \\
\text { Mean }(\mathbf{S . D})\end{array}$ & $\begin{array}{c}\text { Non-Working (n=30) } \\
\text { Mean }(\mathbf{S . D})\end{array}$ & $\begin{array}{c}\text { Total }(\mathbf{n}=\mathbf{6 0}) \\
\text { Mean (S.D) }\end{array}$ \\
\hline Sleep & $7.28( \pm 1.39)$ & $7.16( \pm 0.43)$ & $7.29( \pm 0.55)$ \\
\hline Personal activities & $1.12( \pm 0.44)$ & $3.14( \pm 0.50)$ & $2.20( \pm 0.83)$ \\
\hline Cooking & $2.14( \pm 0.67)$ & $4.05( \pm 0.41)$ & $3.23( \pm 0.18)$ \\
\hline $\begin{array}{l}\text { Other house hold } \\
\text { activities }\end{array}$ & $4.24( \pm 1.17)$ & $4.12( \pm 0.48)$ & $4.13( \pm 0.69)$ \\
\hline Paid work & $7.22( \pm 0.49)$ & - & $3.11( \pm 3.20)$ \\
\hline Rest and recreation & $1.25( \pm 0.85)$ & $5.10( \pm 0.73)$ & $3.19( \pm 1.92)$ \\
\hline
\end{tabular}

Table.4 Details of exercise performed by the selected urban respondents

\begin{tabular}{|l|c|c|c|}
\hline \multicolumn{1}{|c|}{ Exercise Details } & \multicolumn{3}{|c|}{ Urban Women } \\
\cline { 2 - 4 } & Working (n=30) & Non-Working (n=30) & Total (n=60) \\
\hline I. Frequency of doing exercise & & & \\
\hline No exercise & $14(46.67)$ & $13(43.33)$ & $27(45.00)$ \\
\hline Daily & $14(46.67)$ & $11(36.67)$ & $25(41.67)$ \\
\hline Weekly & $2(6.67)$ & $2(6.67)$ & $4(6.67)$ \\
\hline Occasionally & - & $4(13.33)$ & $4(6.67)$ \\
\hline II. Type of exercise & & & $14(23.33)$ \\
\hline Walking & $7(23.33)$ & $7(23.33)$ & $10(16.67)$ \\
\hline Yoga & $5(16.67)$ & $5(16.67)$ & $5(8.33)$ \\
\hline Physical exercise & $3(10.00)$ & $2(6.67)$ & \\
\hline Both walking and exercise or & $1(3.33)$ & $3(10.00)$ & \\
\hline Walking, exercise and yoga & & & $4(6.67)$ \\
\hline III. Time spent for exercise(Min) & & & $12(20.00)$ \\
\hline \multicolumn{1}{|c|}{$\mathbf{1 0}$} & $1(3.33)$ & $3(10.00)$ & $8(13.33)$ \\
\hline $\mathbf{2 0}$ & $7(23.33)$ & $5(16.67)$ & $5(8.33)$ \\
\hline $\mathbf{4 0}$ & $4(13.33)$ & $4(13.33)$ & $2(3.33)$ \\
\hline $\mathbf{5 0}$ & $2(6.67)$ & $3(10.00)$ & $2(3.33)$ \\
\hline $\mathbf{6 0}$ & $1(3.33)$ & $1(3.33)$ & \\
\hline & $1(3.33)$ & $1(3.33)$ & \\
\hline
\end{tabular}


Table.5 Physical and physiological parameters of the subjects selected for experiment

\begin{tabular}{|l|c|c|c|}
\hline $\begin{array}{l}\text { Physical and physiological } \\
\text { Parameters }\end{array}$ & $\begin{array}{l}\text { Urban Working } \\
\text { Women }(\mathbf{n}=\mathbf{3 0})\end{array}$ & $\begin{array}{l}\text { Urban Non-Working } \\
\text { Women }(\mathbf{n}=\mathbf{3 0})\end{array}$ & Total $(\mathbf{N}=\mathbf{6 0})$ \\
\hline Height $(\mathrm{cm})$ & $158.12( \pm 12.18)$ & $162.57( \pm 11.57)$ & $160.35( \pm 11.99)$ \\
\hline Weight $(\mathrm{Kg})$ & $59.40( \pm 9.78)$ & $54.50( \pm 7.99)$ & $56.95( \pm 9.19)$ \\
\hline $\begin{array}{l}\text { Blood pressure systolic/diastolic } \\
(\mathrm{mm} / \mathrm{Hg})\end{array}$ & $\begin{array}{l}118.72 / 80.07 \\
(19.12 / 12.62)\end{array}$ & $\begin{array}{c}120.73 / 81.70 \\
(7.61 / 7.91)\end{array}$ & $119 / 80( \pm 9 / \pm 8)$ \\
\hline Pulse rate & $80.73( \pm 8.33)$ & $81.50( \pm 7.92)$ & $81.11( \pm 8.13)$ \\
\hline Grip strengthof right hands $(\mathrm{Kg})$ & $14.68( \pm 3.49)$ & $13.10( \pm 2.52)$ & $13.89( \pm 3.14)$ \\
\hline Grip strengthof left hands $(\mathrm{Kg})$ & $14.55( \pm 3.38)$ & $12.96( \pm 2.69)$ & $13.76( \pm 3.15)$ \\
\hline Body temperature $\left(\mathrm{C}^{\circ}\right)$ & $96.80( \pm 1.00)$ & $96.75( \pm 1.88)$ & $96.78( \pm 1.49)$ \\
\hline Fat weight $(\mathrm{kg})$ & $12.17( \pm 3.74)$ & $11.55( \pm 2.74)$ & $11.86( \pm 3.28)$ \\
\hline Lean body mass $(\mathrm{kg})$ & $47.23( \pm 7.07)$ & $42.95( \pm 6.21)$ & $45.09( \pm 6.94)$ \\
\hline Per cent fat $(\%)$ & $20.19( \pm 4.22)$ & $21.11( \pm 3.48)$ & $20.65( \pm 3.86)$ \\
\hline Body density & $1.05( \pm 0.01)$ & $1.05( \pm 0.01)$ & $1.05( \pm 0.01)$ \\
\hline
\end{tabular}

Table.6 Distribution of respondents according to body mass index, body type and $\mathrm{VO}_{2} \mathrm{Max}$

\begin{tabular}{|l|l|l|c|}
\hline \multicolumn{1}{|c|}{ Parameters } & \multicolumn{1}{|c|}{$\begin{array}{c}\text { Working } \\
(\mathbf{n = 3 0})\end{array}$} & \multicolumn{1}{|c|}{$\begin{array}{c}\text { Non-Working } \\
(\mathbf{n = 3 0})\end{array}$} & $\begin{array}{c}\text { Total Frequency } \\
(\boldsymbol{\%})\end{array}$ \\
\hline Body mass index & $4(13.33)$ & $6(20.00)$ & $10(16.67)$ \\
\hline CED grade-III Severe (<16) & $1(3.33)$ & $10(33.33)$ & $11(18.33)$ \\
\hline CED grade-II Moderate (16-17.0) & $8(26.67)$ & $3(10.00)$ & $11(18.33)$ \\
\hline CED grade-I Mild (17.0-18.5) & $5(16.67)$ & $9(30.00)$ & $14(23.33)$ \\
\hline Low weight normal (18.5-20.0) & $12(40.00)$ & $2(6.67)$ & $14(23.33)$ \\
\hline Normal (20.0-25.0) & & & \\
\hline Body type & $0(0.00)$ & $4(13.33)$ & $4(6.67)$ \\
\hline Ectomorph(< 20) & $19(63.33)$ & $23(76.67)$ & $42(70.00)$ \\
\hline Mesomorph (21-25) & $11(36.67)$ & $3(10.00)$ & $14(23.33)$ \\
\hline Endomorph(> 25) & & & $7(11.67)$ \\
\hline VO) Max & $3(10.00)$ & $4(13.33)$ & $16(26.67)$ \\
\hline Low average ( 16.0- 25.0 ) & $8(26.67)$ & $8(26.67)$ & $35(58.33)$ \\
\hline High average (26.0- 30.0) & $18(60.00)$ & $17(56.67)$ & $2(3.33)$ \\
\hline Good (31.0- 40.0) & $1(3.33)$ & $1(3.33)$ & \\
\hline Very good ( 41.0- 45.0) & &
\end{tabular}

Table.7 Physical fitness index of selected urban women

\begin{tabular}{|l|c|}
\hline \multicolumn{1}{|c|}{ Physical fitness index } & Total Urban Women Frequency $(\boldsymbol{\%})$ \\
\hline Poor $(<80)$ & $2(6.67)$ \\
\hline Low average $(81-100)$ & $16(53.33)$ \\
\hline High average $(101-115)$ & $8(26.67)$ \\
\hline Good $(116-135)$ & $4(13.33)$ \\
\hline
\end{tabular}


Among urban working women category majority of the women $(60.00 \%)$ were in good category $\left(\mathrm{VO}_{2}\right.$ Max category ranging from 31 to $40 \mathrm{ml} / \mathrm{kg} \times \mathrm{min}$ ) followed by 26.67 per cent belonged to high average $\left(\mathrm{VO}_{2} \mathrm{Max}\right.$ of $26-30 \mathrm{ml} / \mathrm{kg} \times \mathrm{min}$ ) range, 10.00 per cent in low average $\left(\mathrm{VO}_{2}\right.$ Max of $16.0-25.0 \mathrm{ml} / \mathrm{kg} \times$ min) range. and Only 3.33 per cent were in very good $\mathrm{VO}_{2}$ Max rang. In urban nonworking category the majority of the women $(56.67 \%)$ were in good category $\left(\mathrm{VO}_{2}\right.$ Max ranging from 31-40 $\mathrm{ml} / \mathrm{kg} \times \mathrm{min}$ ) followed by 26.67 per cent falling in high average $\left(\mathrm{VO}_{2}\right.$ Max of $\left.26-30 \mathrm{ml} / \mathrm{kg} \times \mathrm{min}\right)$ range, 13.33 per cent low average $\left(\mathrm{VO}_{2} \mathrm{Max}\right.$ of $16.0-25.0 \mathrm{ml} / \mathrm{kg} \times \mathrm{min}$ ) range and only 3.33 per cent had very good $\mathrm{VO}_{2}$ Max range as presented in table- 6 .

The table-7 shows that Majority of the urban respondents $(53.33 \%)$ belonged to low average physical fitness level followed by High average $(26.67 \%)$, good $(13.33 \%)$ and poor $(6.67 \%)$ physical fitness level as depicted in table-18. None of the respondents were either in very good or excellent category of physical fitness Index. None of the respondents were either poor or very good or excellent category of physical fitness Index. Indian women spend a considerable amount of time and energy while performing household activities therefore is a general complement of feeling tired towards the end of the day.

Therefore, knowledge of their aerobic capacity can be of greater practical importance in determining the fitnessdemand compatibility and organization work and work method to ensure optimal performance with least physical effort and fatigue. For better efficiency and work output, they should be trained to use the improved technologies. Good health provides sound and solid foundation on which fitness rests and at the same time fitness provides one of the most important key to health and living one's life to fullest. Physical fitness is the important factors to perform of any physical activity. It is considered to be the best measure of an individual's cardio-respiratory fitness or capability for doing physical work. It can serve as a reliable yardstick to judge whether an individual will be able to accomplish a given task without any signs of fatigue or discomfort.

\section{Recommendations}

None of the respondents were either poor or very good or excellent category of physical fitness Index. They belonged to low average and high average physical fitness level. Indian women spend a considerable amount of time and energy while performing household activities therefore is a general compliant of feeling tired towards the end of the day. Therefore, knowledge of their aerobic capacity can be of greater practical importance in determining the fitnessdemand compatibility and organization work and work method to ensure optimal performance with least physical effort and fatigue. For better efficiency and work output, they should be trained to use the improved technologies.

\section{References}

Choudhary, A., 1998, Physical Fitness of Female Students Studying in High Schools in Rural and Urban Areas. M.Phil Thesis, Unpublished. Kurukshetra: Kuruskhetra University.

Bouchard, C. and Shephard, R.J., 1994, Physical Activity Fitness and Health: International Proceedings and Consensus Statement, Human Kinetics, (3): 77-88.

Garrow, G.H. 1987, Quetelets index as measure of fatness. Internat. J. Obesity, 9:147-153. 
Saha, P.N., Varghese, M.A., and Bhatnagar, A. 1996, Ergonomics research of women in India - A monograph of Post Graduate Department of Family Resource Management, SNDT Women's University, Mumbai.

Verghese, M. A., Saha, P. N. and Aterya, N.,
1994, A rapid appraisal of occupational work load, modified scale perceived exertion. Ergonomics, 37: 485-495.

World Health Organization, 1981, Global Health for All Strategy by 2000. Geneva, health for all (3).

\section{How to cite this article:}

Channamsetty Mahalakshmi, Suma Hasalkar, SaritaKumari, Mani Bhushan. 2020. Health Status and Physical Fitness of Urban Working and Non -Working Women in Dharwad Taluk, India. Int.J.Curr.Microbiol.App.Sci. 9(06): 335-344.

doi: https://doi.org/10.20546/ijcmas.2020.906.044 